Article

\title{
Road Infrastructure Analysis with Reference to Traffic Stream Characteristics and Accidents: An Application of Benchmarking Based Safety Analysis and Sustainable Decision-Making
}

\author{
Syyed Adnan Raheel Shah * and Naveed Ahmad \\ Taxila Institute of Transportation Engineering, Department of Civil Engineering, University of Engineering \& \\ Technology, Taxila 54890, Pakistan; n.ahmad@uettaxila.edu.pk \\ * Correspondence: shahjee.8@gmail.com or Syyed.adnanraheelshah@uhasselt.be; Tel.: +92-300-79-14-248
}

Received: 23 March 2019; Accepted: 17 May 2019; Published: 5 June 2019

check for updates

\begin{abstract}
Road infrastructure sustainability is directly associated with the safety of human beings. As a transportation engineer and policymaker, it is necessary to optimize the funding mechanism for road safety improvement by identifying problematic road segments. Infrastructure improvement is one of the key targets for efficient road safety management. In this study, data envelopment analysis (DEA) technique has been applied in combination with a geographical information system (GIS) to evaluate the risk level of problematic segments of a $100 \mathrm{~km}$-long motorway (M-2) section. Secondly, the cross efficient method has been used to rank the risky segments for prioritization and distribution of funding to improve the road safety situation. This study will help in efficiently identifying the risky segments for safety improvement and budget allocation prioritization. GIS map will further improve the visualization and visibility of problematic segments to easily locate the riskiest segments of the motorway.
\end{abstract}

Keywords: sustainability; road infrastructure; safety; accidents; decision making

\section{Introduction}

Road traffic accidents are avoidable events which are increasing in frequency day by day. According to a report of $\mathrm{WHO}$, the road accidents are facing a growing trend and there will be an $80 \%$ increase in accidents from 2000 to 2020 [1-3]. Most of the road accidents occur in low- and middle-income countries $[4,5]$. In developing countries, it has become an important social as well as economic burden over the citizens because death, disability, and long-term health care creates a large financial burden [6,7]. Disabled people have increased living costs which pushes poor families towards worse financial positions.

It has been observed by various studies [8,9] that fatalities in road accidents are decreasing in high-income countries. However, the rate of casualties is facing a growing trend in low-income countries. Road accidents are now as critical as any other health disease as a top ten contender of human health problems and are a threat to the lives of the general public. Road accidents may result from environmental factors such as weather conditions, physical factors such as road conditions, and human factors such as drivers' behavior and state during driving. Thus society and state should consider these factors important and measures should be taken, keeping the above mentioned factors in view, to prevent and avoid road accidents $[10,11]$.

Road accident data analysis as a perspective of engineers revolves around the two major factors: (i) traffic characteristics and (ii) geometric design. Because of that reason, hotspot identification of accident-prone locations remains a focal point of interests for transportation engineers. That is 
why a series of researches were involved in relationship analysis of accidents [12-23] in context of volume/capacity (V/C) [18,19,24,25], vehicles miles travelled (VMT) [17,26-29], vehicles hours travelled (VHT) [25,30,31], speed [18,20,24,32-38], flow [12,13,32,35,36,39], and geometric design [35,40-44]. Different methods were applied to locate the risky road segments to be treated for safety level enhancement. Motorways and highways remained a major target of analysis of safety improvements for safety scientists. Researchers [45-51] not only explored the road accidents model development for prediction and analysis, but also discussed the low and higher cost treatments to solve the safety problems [52-56]. This study focuses on the identification of accident-prone segments of roads for safety analysis.

Pakistan is a densely populated, developing country with low per capita income. In past years, Pakistan has experienced a slow economic growth and a consequent lesser improvement in road infrastructure, while vehicle use for transportation has increased during the last decade $[57,58]$ and road safety situation is still not improving as more than 4000 people are killed and almost 10,000 are injured every year due to traffic accidents. Statistics show that accident and fatalities decreased between 2009 to 2014 but an increasing trend can be seen for 2015 (see Figure 1). A growing number of vehicles increases the probability of accidents and the vulnerability of road users. Road accident fatalities and handicaps have been found to be higher than any other injury category in Pakistan during a health survey [58]. It is a challenge for all the national leaders to immediately pay attention to this increasing issue as a policymaker [59]. Thus, the need for research arises to find out the possible causes of road accidents which either injure or kill people, and scientifically study such causes to provide practical remedial measures.

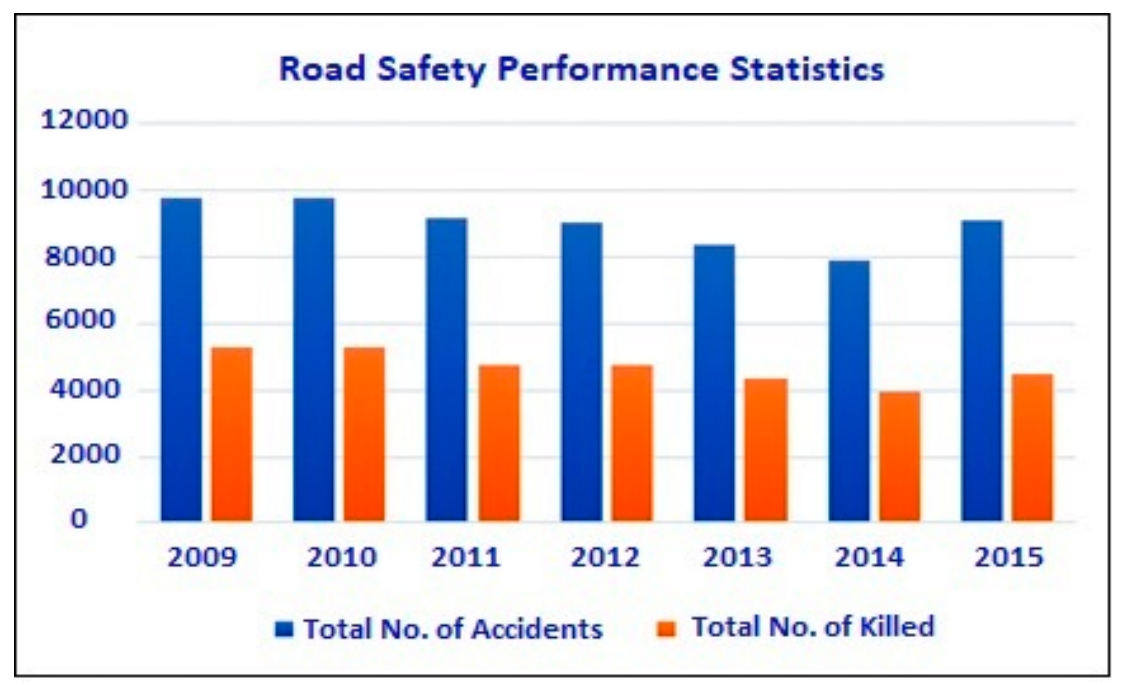

Figure 1. Road accident statistics of Pakistan (Source SBP [60]).

During the analysis of motorways and highways, the identification of hazardous road locations and blackspots provides an opportunity to improve road safety conditions of the areas [61-74]. From the previous researches, a theoretical definition of a hazardous accident prone road location is discussed as a hazardous/problematic road segment or location is any point that (a) has a higher number of expected or occurring accidents [68] in comparison to similar road locations (i.e., within the same region or on the same road) (b) also include local risk factors. Among these two points was a largely unanimous agreement on the high number of accidents noted during a specific period [69]. However, road safety targets which are based on the safety auditing and the factor of sustainable safe traffic [75] are key points to be considered. In this regard, in Sweden, the concept of Vision Zero has been applied, and the Netherlands and the United Kingdom are following the strategy of 'Tomorrow's roads-safer for everyone' as a line of further action [76]. Under the justifiable road safety vision, five points are focused on: roads usage, formation of speed and direction, certainty in road user behavior 
with reference to standard based road design, environmental impact, and knowledge level the road user [77-79]. In addition to that, road safety data quality and historic data collection are important for road safety analysis as measuring the risk is associated with accidents with reference to exposure and cost [80]. Researchers have focused on two major sections of the traffic system components (vehicles, road users, and infrastructure) and stake-holders (users, government, manufacturers, and planners) to improve the human safety on roads, which is considered as the ultimate responsibility of the state [81]. Within a country, a major source of high-speed transportation is motorways and highways. During the accident analysis of motorways and highways, researchers have focused on relationship analysis of accidents and traffic features. A series of researchers have focused on defining the relationship between the accident and traffic volumes, either at the aggregated (e.g., annual average daily traffic or (AADT)) or disaggregated (e.g., hourly volumes) levels [15,30,82-86]. Further work has also scrutinized the safety of highway segments as a function of other traffic flow features, such as V/C ratios [19,25,26,40], vehicle density or occupancy $[35,87,88]$ and speed distribution [32,89-92].

So, the safety features are related to changes in traffic conditions and design as well. Similarly, two major factors are involved in the safety phase i.e., cost analysis to adopt a certain strategy based on its importance and technical decision-making based on requirement or compulsion. It is proposed that to improve safety efficiency and to analyze the safety performance, a high-quality data source is required. But in developing countries where sources are not available, aggregate data approaches are used. In the case of motorways or highways, the segment-based study provides a benefit to analyze and treat the problematic segment for efficient decision making. Worldwide, different methods are applied to analyze the road safety conditions of motorways and highways, but some exemplary models used in other parts of the countries have shortcomings. In Pakistan, motorways are also one of the major contributors to road accidents. The comparative statistics of road accidents and fatalities on motorways and highways of Pakistan are shown in Figure 2. The comparative analysis shows an increasing trend in fatalities from 2013 to 2014 which indicates that it is necessary to analyze and improve the safety condition of motorways and highways.

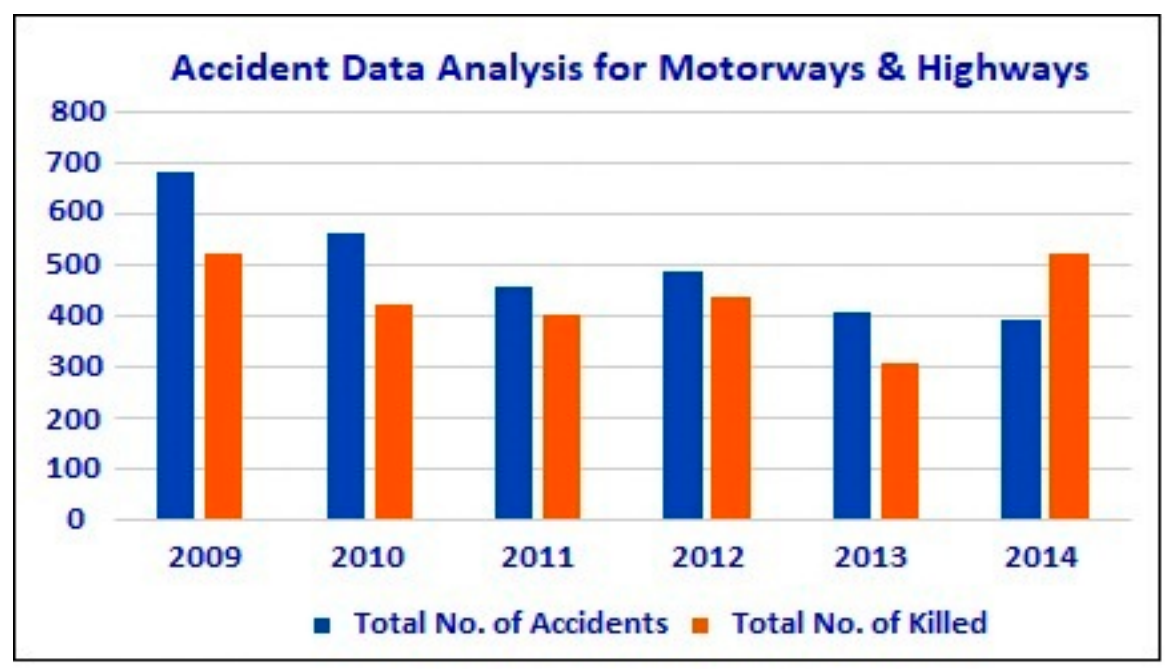

Figure 2. Accident statistics of motorways and highways of Pakistan (Source NH and MP [93]).

The present study focuses on the analysis of motorways and to identify the problematic section for safety improvement. Road accidents are measured as to their severity. A road accident usually results in injuries which may cause on spot casualty or may eventually lead to death. Considering accidents, traffic volume/capacity, and vehicle kilometers traveled, their relationship with road accident severity is explored using a benchmarking technique which can be applied in any condition worldwide. 


\section{Road Accident Risk Index and Benchmarking}

Road accidents and traffic engineering are two streams of the same channel. To calculate the risk associated with the road safety, a composite index is used to evaluate the road safety level of certain entities i.e., roads. The simplest relationship used to evaluate the road safety risk [94-97] is as shown in Equation (1):

$$
\text { Risk }=\frac{\text { Road Safety Outcome }}{\text { Exposure }}
$$

In case of countries, exposure was measured as passenger kilometers traveled, population and number of registered vehicles $[14,15]$ but in case of highways, it has been considered as volume/capacity, vehicle miles traveled and vehicles hours traveled [94]. Some have explained exposure as traffic flow and traffic composition [54]. However, road safety outcome indicates the number of accidents, number of fatalities and injuries, and property damages [98].

During the financial decision-making process and for the safety of humans, it is necessary to analyze the road safety performance of roads [98]. To conduct the research regarding road safety performance analysis benchmarking has a vital role [16-18]. Following the concept of multiple outputs and multiple inputs, data envelopment analysis (DEA) is one of the popular methods based on the linear program (Figure 3). For the first time in 1978, Charnes et al. [19] applied a linear program to evaluate the effectiveness of the system by applying to benchmark (frontier) based concept [19]. During the application of DEA, for calculation of efficiency, concept of maximizing output and minimizing input is used, however in the field of road safety, during calculation of risk this concept works in reverse order and logic of minimizing output and maximizing input works. So, the number of traffic accidents, to be as low as possible with respect to the level of exposure i.e., V/C, VMT and VHT. Road segments are considered as decision making units (DMUs) and the basic target is to identify the best-performing road segments and worst as well. Best are those with minimum output levels given the input exposure variables, and other segments' risk is then measured relative to this frontier [20].

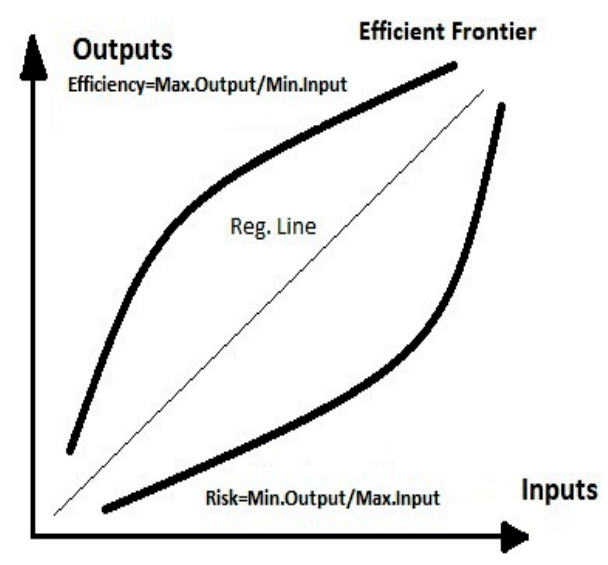

Figure 3. Basic data envelopment analysis (DEA) model conceptual diagram.

Mathematically, to use DEA for road safety evaluation, the model is shown as follows:

$$
\begin{gathered}
E_{0}=\max \frac{\sum_{r=1}^{s} u_{r} y_{r^{0}}}{\sum_{i=1}^{m} v_{i} x_{i 0}} \\
\text { subject to } \frac{\sum_{r=1}^{s} u_{r} y_{r j}}{\sum_{i=1}^{m} v_{i} x_{i j}} \leq 1, j=1, \ldots, n \\
u_{r}, v_{i} \geq 0, r=1, \ldots \ldots, s, i=1, \ldots, m
\end{gathered}
$$

where $y_{r j}$ and $x_{i j}$ are the $r$ th output and $i t h$ input respectively of the $j t h \mathrm{DMU}, u_{r}$ is the weight given to output $r$, and $v_{i}$ is the weight given to input $i$. 
Previously DEA was used to calculate the road safety index for 21 European countries [16] and for ideal trauma management regarding road safety [21]. For the calculation of risk value for European countries: population, passenger-kilometers, and passenger cars were used as inputs and the number of fatalities as output $[22,94]$. Yearly comparative performance of road safety program was evaluated by the DEA technique [23,94]. In Brazil, 27 states were considered for road safety risk evaluation by using the concept of death rate (fatalities per capita) and casualty rate (fatalities per vehicle and fatalities per vehicle kilometer traveled) [24,94]. In Belgium, motorways were analyzed for road safety risk analysis according to a similar concept of input and output by applying DEA [94]. The road accident risk index is an established concept in the field of road safety and the formulation for road safety has been explained by many researchers $[19,20]$ as.

Risk: basic concept of Risk calculation is as:

$$
\begin{gathered}
\text { Risk }=\frac{\text { Wt.Sum of Outputs }}{\text { Wt. Sum of Inputs }}=\frac{\text { Min. Outputs }}{\text { Max. Inputs }} \\
\text { Road Accident Risk Index }=\frac{\text { Min. Outputs }}{\text { Max. Inputs }}=\frac{\text { Safety Outcome }}{\text { Exposure }}
\end{gathered}
$$

Risk: basic concept of DEA-Risk calculation is as:

$$
\text { Risk }=\frac{U_{1}\left(y_{1 j}\right)+U_{2}\left(y_{2 j}\right)+\ldots+U_{\mathrm{k}}\left(y_{k j}\right)}{V_{1}\left(x_{1 j}\right)+V_{2}\left(x_{2 j}\right)+\ldots+V_{1}\left(y_{l j}\right)}
$$

where

$u_{k}=$ weights of output $k, y_{k j}=$ amount of output $k$ from unit $j, v_{l}=$ Weights for inputs $l$, and $X_{l j}=$ amount of iutput l to unit $j$.

\section{Materials and Methods}

\subsection{Framework for Research Design}

The methodology of applying DEA for road safety accident data analysis has been shown in Figure 4.

Step 1. Study area selection and segmentation of motorway (M-2) on per km basis.

Step 2. Selection of accident-prone segments naming them as decision-making units (DMUs).

Step 3. Selection of variables for calculating traffic accident risk index.

- $\quad$ Output variables were separated as number of accidents (NoA) and number of affected people (NoAP)-killed or injured.

- $\quad$ Input variables were separated as volume/capacity, vehicles km travelled and vehicles hrs Travelled.

Step 4. Application of DEA program using Lingo Software with the concept of minimizing accidents and killing/injuries and maximizing traffic exposure (V/C, VKT, VHT) to calculate composite traffic accident risk index.

Step 5. Application of cross efficient methodology to calculate a unique value of the traffic accident risk index for each DMU and severity ranking.

Step 6. Application of GIS mapping to produce a visual understanding of risk-prone locations on motorways.

Step 7. Discussion about top ten risky motorway sections and decision-making. 


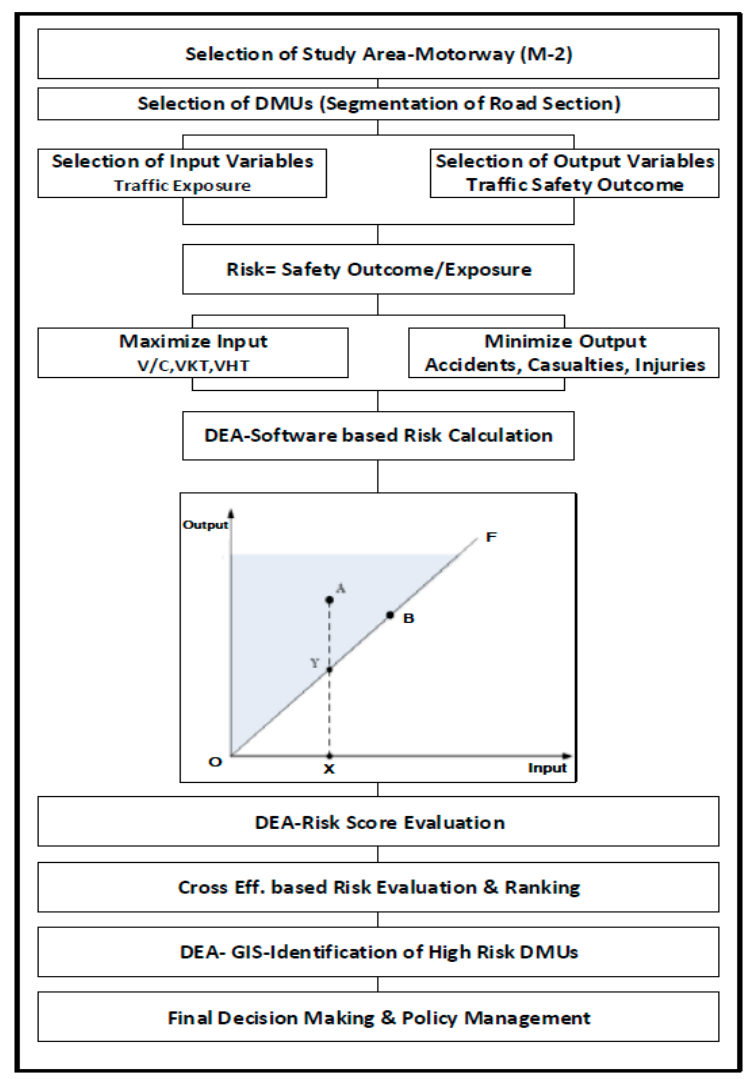

Figure 4. Methodological framework. DMUs: decision-making units; GIS: geographical information system; V/C: volume/capacity; VKT: vehicle kilometers travelled; VHT: vehicle hours traveled.

\subsection{Study Area}

The study area selected for accident data analysis is Lahore-Islamabad Motorway (M-2), the section between Milepost (200-300 km shown in Figure 5) which is potentially considered as one of the most problematic section with respect to road safety.

\subsection{Data Description and Preparation}

In order to develop a statistical association between traffic factors and road accident severity, the data was collected from National Motorways and Highway Police (NHM\&P) and National Highway Authority (NHA) for the Motorway (Lahore-Islamabad section: 200-300 km) for six years (2009-2014) as shown in Table 1. Number of accidents (NOA) and number of affected persons i.e., injured or killed (NOAP) were safety outcome or outputs. Data output variables were tested for Isotonic behavior having a positive correlation between them.

Table 1. Description for road accident data analysis.

\begin{tabular}{|c|c|c|c|c|c|c|c|c|c|c|}
\hline Stage & Variable & Description & $\mathbf{N}$ & Mean & SD & Min. & Q1 & Med. & Q3 & Max. \\
\hline \multirow{2}{*}{ Output } & NOA & No. of accidents & 99 & - & - & 1 & 1 & 1 & 2 & 14 \\
\hline & NOAP & $\begin{array}{l}\text { No. of affected persons: } \\
\text { killed or injured }\end{array}$ & 99 & - & - & 1 & 2 & 4 & 7 & 162 \\
\hline \multirow{3}{*}{ Input } & $\mathrm{V} / \mathrm{C}$ & Volume/capacity & 99 & 0.050 & 0.006 & 0.042 & 0.045 & 0.047 & 0.056 & 0.060 \\
\hline & VKT & $\begin{array}{l}\text { Vehicle kilometers } \\
\text { traveled }\end{array}$ & 99 & 8562 & 1077 & 7301 & 7838 & 8092 & 9690 & 10375 \\
\hline & VHT & Vehicle hours traveled & 99 & 7486 & 4324 & 3877 & 4855 & 5509 & 7781 & 19421 \\
\hline
\end{tabular}

Note: $\mathrm{N}$ = number of road segments (Size-1 km each),

$\mathrm{SD}=$ standard deviation, $\mathrm{Q} 1$ and $\mathrm{Q} 3$ = quartiles of data 


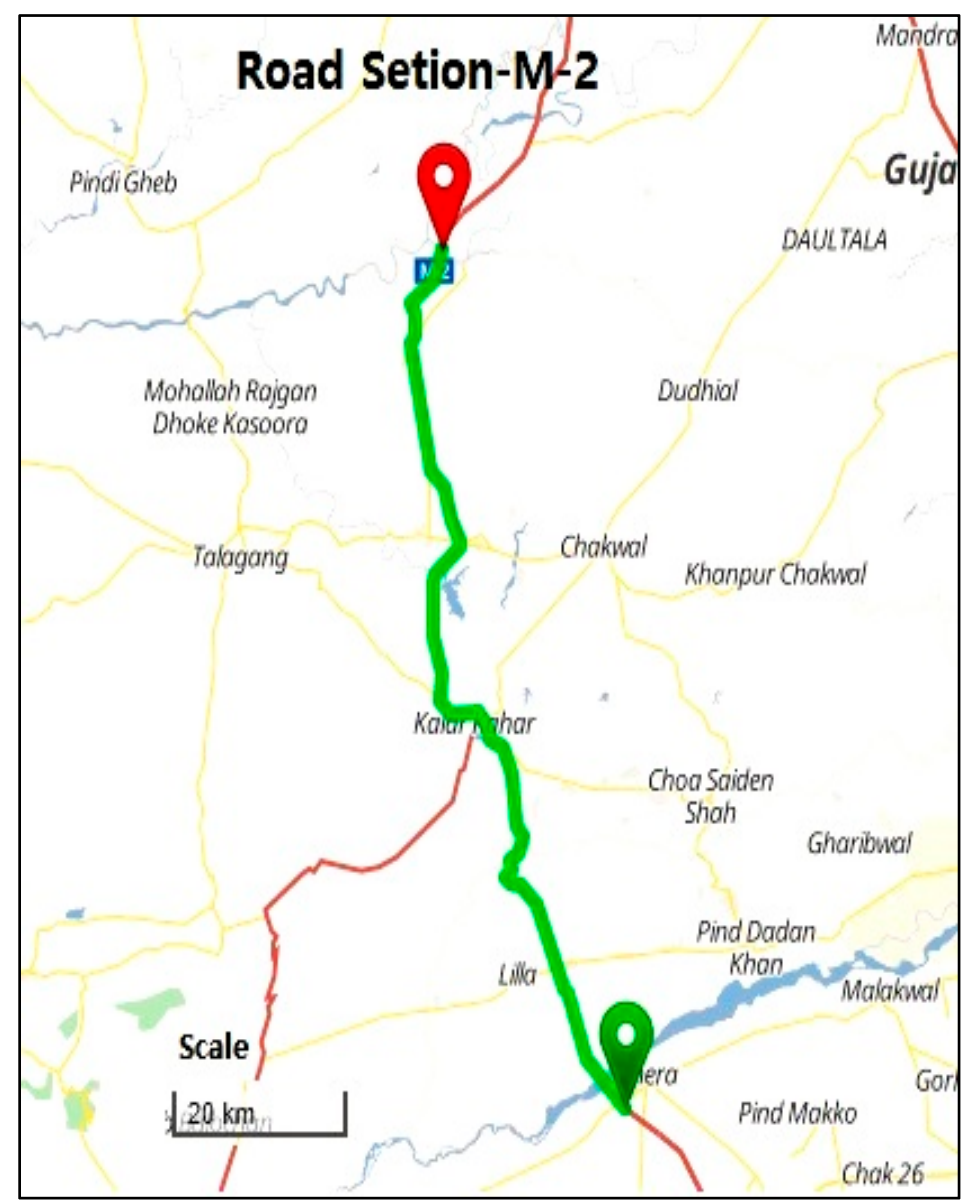

Figure 5. Study area-motorway (M-2) 200-300 km section.

\subsection{Accident Risk Analysis Using Data Envelopment Analysis}

The DEA model has been applied in the field of road safety with the concept to maximize traffic exposure and minimize the accidents. A similar concept has been applied with the optimization tool DEA to calculate the road accident risk index. Safety outcome is considered a reduction in a number of accidents and number of fatalities and injuries with reference to the increase in traffic volume/capacity, vehicles kilometer traveled, and vehicles hours traveled.

By the addition of actually desired variables in Equation (4), for Highway risk evaluation [94] relationship is shown in Equation (5):

$$
\text { Risk }=\frac{U_{2}(N o A)+U_{1}(N o A P)}{V_{1}(V / C)+V_{2}(V K T)+V_{3}(V H T)}
$$

where $U_{1}=$ weights for 1 st output $(N o A), U_{2}=$ weights for 2 nd output $(N o A P) ; V_{1}=$ Weights for 1 st Input $(V / C), V_{2}=$ weights for 2nd Input $(V K T), V_{3}=$ weights for 3rd Input $(V H T)$.

\subsection{Cross Efficiency Calculation for Ranking}

For the prioritization and ranking of Risky DMUs, a cross-efficiency risk matrix (CERM) is applied as a DEA extension tool to assist in analyzing the overall high to low-risk performer among all DMUs and rank them. The DEA Model, which sustains on the principle to assess the performance of road segments (DMUs) as peer assessment instead of a self-assessment concept. Theorem of applying CERM as shown in Table 2 explains the concept that the element of each row is used to calculate the risk for each DMU [98]. 
Table 2. A cross-efficient risk matrix (CERM).

\begin{tabular}{cccccc}
\hline DMU & \multicolumn{5}{c}{ Rated DMU } \\
\hline & 1 & 2 & 3 & $\ldots \ldots$ & $n$ \\
\hline DMU1 & $R_{11}$ & $R_{12}$ & $R_{13}$ & $\ldots \ldots$ & $R_{1 n}$ \\
DMU2 & $R_{21}$ & $R_{22}$ & $R_{23}$ & $\ldots \ldots$ & $R_{2 n}$ \\
DMUn & $R_{n 1}$ & $\frac{R_{n 2}}{R_{2}}$ & $\frac{R_{n 3}}{R_{3}}$ & $\ldots \ldots$ & $\frac{R_{n m}}{R_{n}}$ \\
Mean & $R_{1}$ & $\ldots \ldots$ & $\ldots$ \\
\hline
\end{tabular}

Weights for each DMU were obtained and applied to each data set to obtain an average of risk value by a multiplying weight with each data value, and the average was taken. That average value helped to calculate the best possible risk and to prioritize the risk value for ranking purpose [94].

\section{Results and Discussion}

\subsection{Risk Analysis and Calulations}

The basic theme of applying DEA method was to analyze the comparative safety levels of motorway segments to rank them for prioritizing safety improvements and financial decision making for implementation. High-risk segments could easily be identified but an additional sensitivity analysis method of cross-risk calculation helped in prioritizing the segments for ranking. A standard of 1 served as the benchmark, and an increasing trend indicated the distance from the safety ideal, so the far-most are considered the most dangerous ones. Thus, after applying model (2) for calculating risk $\left(R_{0}\right)$ in accident data analysis and management field, the lowest level must be measured as the frontier of safety. As described above, for ranking purposes, the cross-risk technique [20] has been adopted to obtain the best ranking, as shown in Table 3 .

Table 3. Road accident risk index (RARI) calculation mechanism using DEA.

\begin{tabular}{|c|c|c|c|c|c|c|c|c|c|}
\hline Seg.ID & $\begin{array}{l}\text { Km } \\
\text { Post }\end{array}$ & $\frac{\mathrm{V} / \mathrm{C}}{\text { Input I1 }}$ & $\frac{\mathrm{VKT}}{\text { Input I2 }}$ & $\frac{\text { VHT }}{\text { Input I3 }}$ & $\frac{\text { NOA }}{\text { Output } 01}$ & $\frac{\text { NOAP }}{\text { Output } O 2}$ & DEA-Risk & $\begin{array}{c}R A R I \\
\text { (CE-Risk) }\end{array}$ & Rank \\
\hline $538 B$ & 229 & 0.047 & 8092 & 19,421 & 14 & 162 & 14.00 & 21.81 & 1 \\
\hline $223 \mathrm{~A}$ & 223 & 0.045 & 7838 & 15,676 & 10 & 30 & 10.91 & 13.00 & 2 \\
\hline $229 \mathrm{~A}$ & 229 & 0.045 & 7838 & 15,676 & 8 & 50 & 8.72 & 11.53 & 3 \\
\hline 418B & 223 & 0.047 & 8092 & 19,421 & 8 & 24 & 8.00 & 9.74 & 4 \\
\hline $670 B$ & 224 & 0.047 & 8092 & 19,421 & 5 & 25 & 5.00 & 6.48 & 7 \\
\hline $609 B$ & 286 & 0.056 & 9690 & 7268 & 5 & 12 & 5.35 & 6.11 & 8 \\
\hline $533 B$ & 253 & 0.044 & 7645 & 4059 & 3 & 18 & 4.08 & 5.56 & 9 \\
\hline $432 B$ & 239 & 0.047 & 8092 & 6474 & 4 & 4 & 5.07 & 5.51 & 10 \\
\hline $255 \mathrm{~A}$ & 255 & 0.042 & 7301 & 3877 & 3 & 7 & 4.27 & 5.18 & 11 \\
\hline $225 \mathrm{~A}$ & 224 & 0.045 & 7838 & 15,676 & 3 & 7 & 3.27 & 3.81 & 15 \\
\hline $260 \mathrm{~A}$ & 260 & 0.042 & 7301 & 3877 & 2 & 7 & 2.85 & 3.59 & 16 \\
\hline $286 \mathrm{~A}$ & 286 & 0.060 & 10,375 & 7781 & 3 & 9 & 3.00 & 3.50 & 17 \\
\hline $241 \mathrm{~A}$ & 241 & 0.045 & 7838 & 5879 & 2 & 9 & 2.65 & 3.24 & 18 \\
\hline $661 \mathrm{~B}$ & 211 & 0.049 & 8400 & 4500 & 2 & 9 & 2.45 & 3.22 & 19 \\
\hline $244 \mathrm{~A}$ & 244 & 0.042 & 7301 & 5476 & 2 & 4 & 2.84 & 3.20 & 20 \\
\hline- & - & - & - & - & - & - & - & - & - \\
\hline- & - & - & - & - & - & - & - & - & - \\
\hline 453B & 230 & 0.047 & 8092 & 19,421 & 1 & 1 & 1.00 & 1.14 & 95 \\
\hline $560 \mathrm{~B}$ & 225 & 0.047 & 8092 & 19,421 & 1 & 1 & 1.00 & 1.14 & 96 \\
\hline $293 \mathrm{~A}$ & 293 & 0.060 & 10,375 & 7781 & 1 & 2 & 1.00 & 1.13 & 97 \\
\hline
\end{tabular}


DEA has a major advantage of not having any specific functional form. Additionally, it can deal with various sources of information and different yields. DEA has a few other advantages as it does not require a presumption of a utilitarian structure relating contributions to yields; DMUs considered in DEA are directly looked at against peers or blend of peers. Inputs and yields utilized in DEA can have diverse estimation units. In this investigation, number of accidents (NoA) and number of affected/influenced people injured or killed (NoAP) are considered as two yields, while presentation factors-volume/capacity (V/C), vehicle kilometers traveled (VKT), and vehicle hours traveled (VHT) were considered as three sources of info. The idea of hazards considered in the ideal of hazardous fragments begins with esteem 1, in view of Model (1); its range started at 1 and continues with increment up to 21.81. Portions with the closest incentives to 1 are viewed as protected and the highest value is considered in danger. In the Table 3, a comparative ranking using the cross-risk method [20] to rank the risky segment by prioritization can be seen. The ranking of DMUs was designated to evaluate the risk level of all segments: the risk value of 21.81 was the largest value in the Table 3 and was ranked first (i.e., the riskiest segment). Priority of treatment can also be decided based on this ranking.

GIS-based spatial map of the motorway section is shown in Figure 6. Dark red colored segments highlight the risky segments. Comparative analysis if calculated risk and Number of accidents (NOA) has been shown in Figure 7.

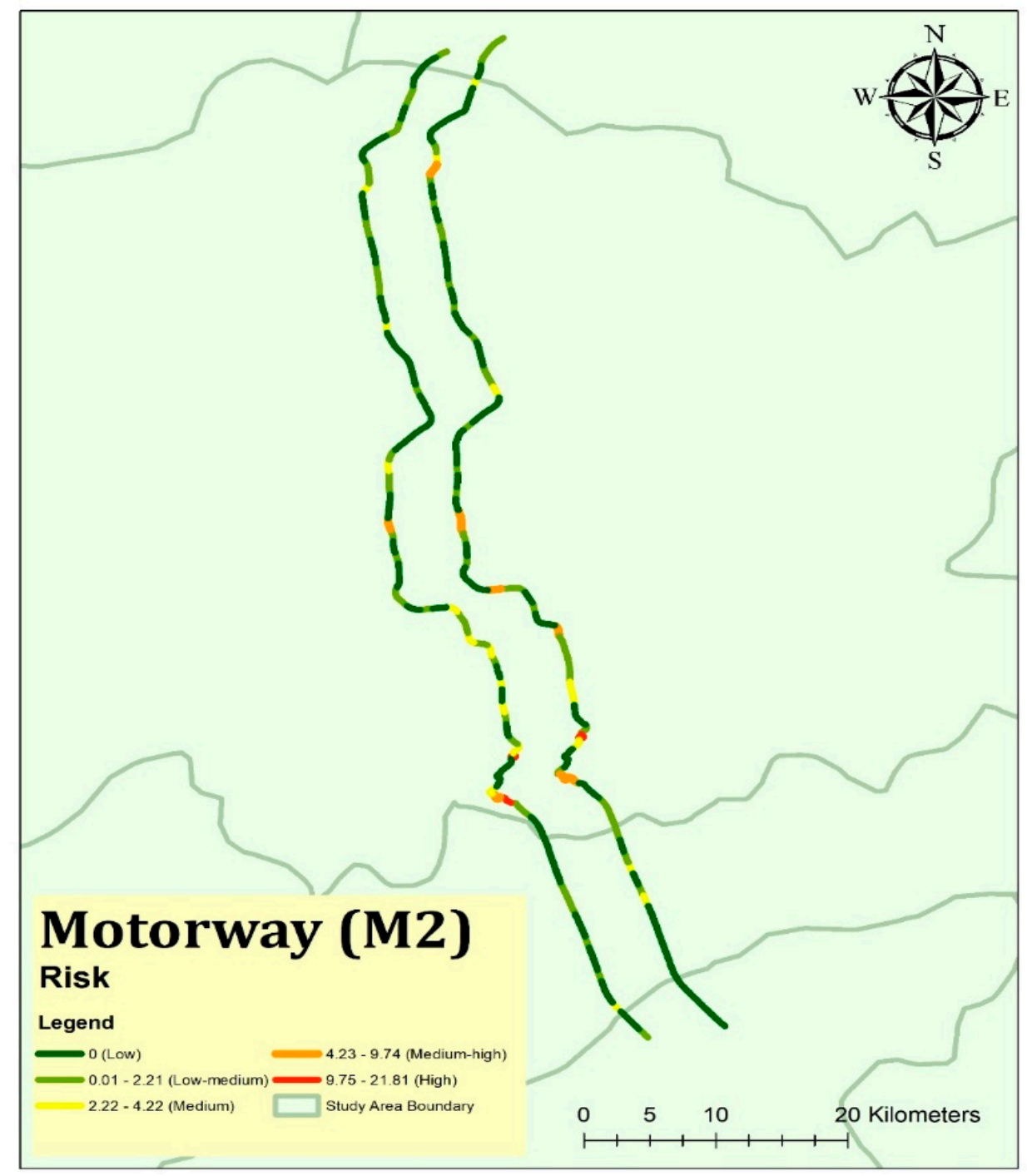

Figure 6. Risk map of motorway (M-2). 


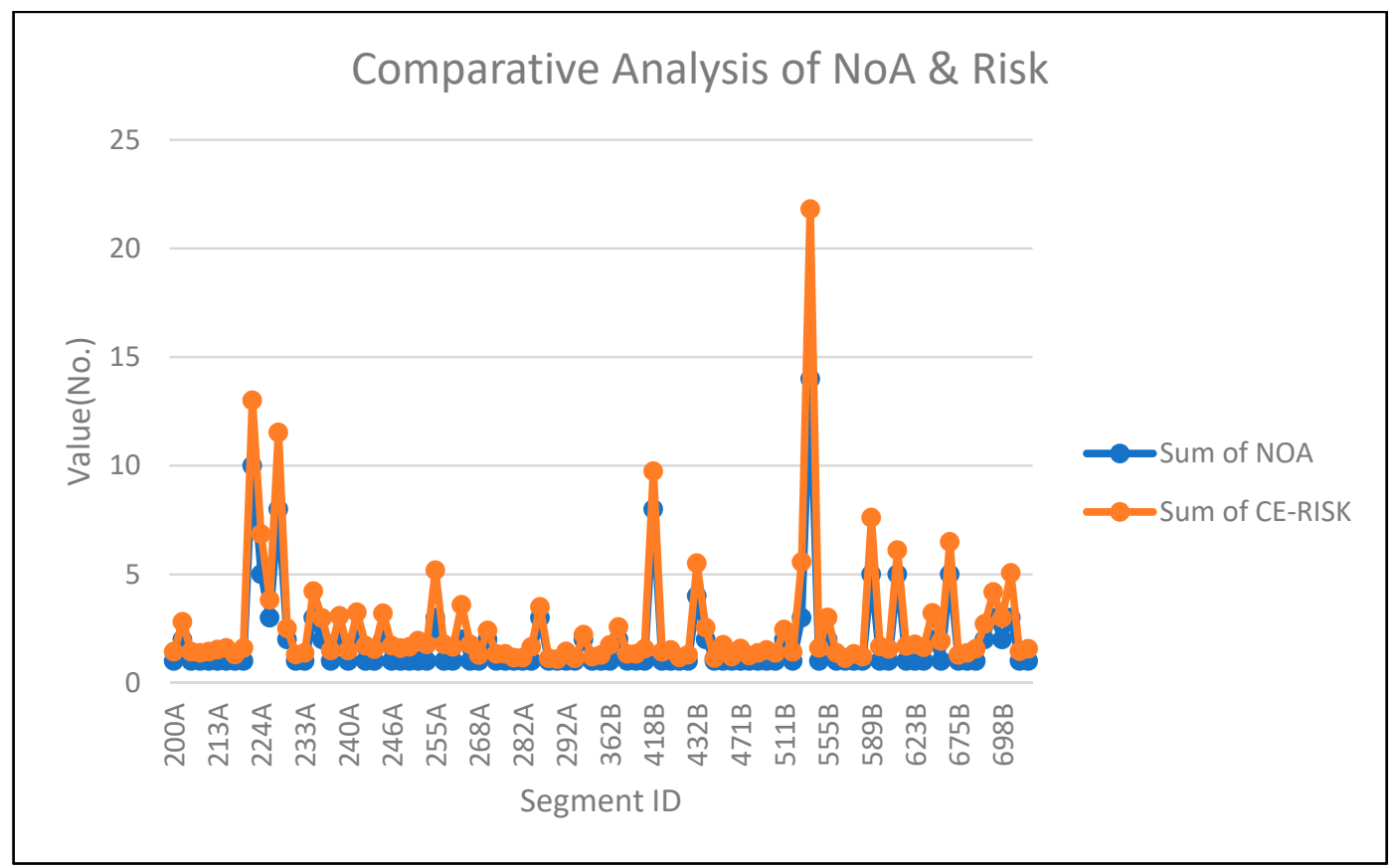

Figure 7. Comparative analysis of number of accidents and risk index.

By applying DEA in combination with GIS, provides a series of benefits. For a 100-km long road, which in fact becomes 200 segments due to one-way traffic (both sides), only 99 problematic segments were studied. By further focusing on the problematic segments and taking the opportunity to identify riskiest segments, DEA helped in locating those segments. CERM helped as an extension to DEA to prioritize the risky road segments based on severity. The segment at the $229 \mathrm{~km}$ spot is one of the key examples of that analysis which is numbered as 1 in the riskiest segment list. With this technique, the first ten or twenty segments can be prioritized and identified for treatment. Otherwise dealing with each segment will be problematic and time-consuming.

\subsection{Risky Segment Identification and Impact on Human Safety}

Considering the case study of the 100-km long motorway (M-2) section for road safety analysis provides an opportunity to analyze the application of a new technique DEA for identification of risky road segments. During the application of DEA, data sets of two types were used. One was output data and other was input data. Output consisted of two major concerning variables: number of accidents and number of affected people (killing/injuries). Input consisted of three major inputs known as exposure variables related to traffic, i.e., VKT, VHT, and V/C. Usually with the increase of road traffic, accidents also increase, that is why exposure is necessary to be considered for analysis if we analyze the specific range of DEA-based calculations of risky segments and their ranking. Out of the top ten, seven are in the same range of Kallar Kahar (mountainous region). So, a focused technical analysis is required to identify the problems of that region. Another benefit of applying DEA is that one does not have to analyze all the 200 road segments (100 section each has two segments on both direction). Just consider only those segments whom have at least one accident during last years (the majority of the researchers have considered data within 3-5 years). Now after ranking, one can easily focus and identify the technical problem in that particular segment. Segments of sections at $229 \mathrm{~km}$, $223 \mathrm{~km}, 224 \mathrm{~km}, 246 \mathrm{~km}, 286 \mathrm{~km}, 253 \mathrm{~km}$, and $239 \mathrm{~km}$ were found to be the top-ten risky segments with respect to traffic exposure. Technical analysis also possibly confirmed that there may be problems with speeding and geometry because flow is already controlled by access. In Figure 8, the geometric problem can be observed. So, technical solutions will revolve around controlling speed and geometry design i.e.; re-analysis and re-designing. 


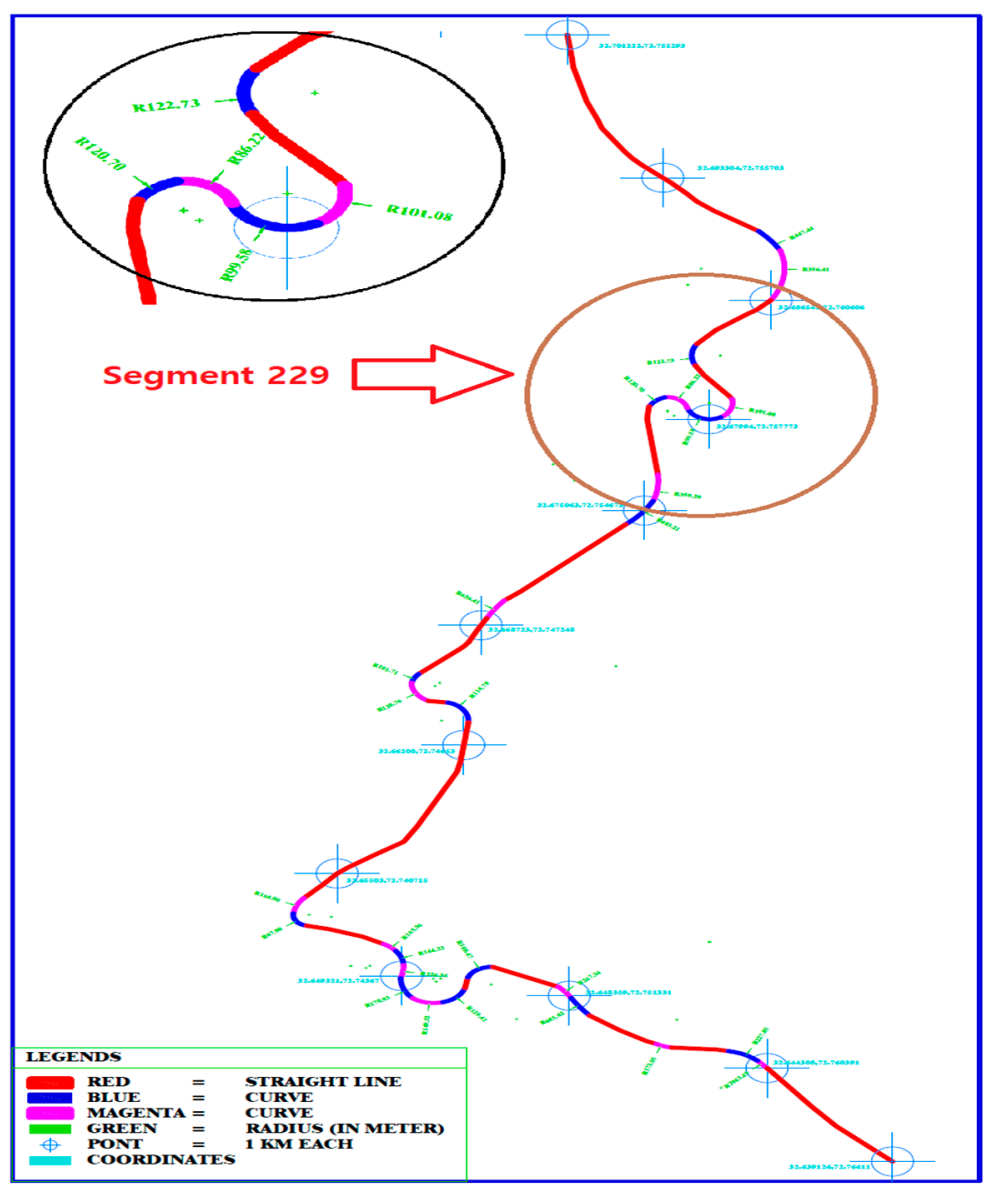

Figure 8. Ranked No.1 top-most risky segment.

Furthermore, the whole story revolves around the human lives which are associated with road safety improvement. Targets like Zero Visions are also set to save human lives on roads. For instance, if we consider that we can only treat the first 20 segments due to budget limitations, an area with $51 \%$ of the accidents and $59 \%$ of killings and injuries can be addressed, which is a huge success to improve the protection of human lives on roads.

\subsection{Safety Management Financial Decision Making}

In most studies, the major focus of engineers revolves around the identification of risky zones on highways which are related to infrastructure and traffic conditions. Identification of black spots on highways always remains a core factor for road safety analysis [99]. Consider funding of 10 million rupees allocated for road safety management of this motorway. That amount cannot be spent on a $100 \mathrm{~km}$ long route: for efficient utilization of that funding a method is required that can help in allocating that funding for an optimum solution.

DEA helps in ranking the segments based on its reverse-efficient level-concept known as a 'risk' to find the riskiest road segments. After ranking of these segments, funding can be allocated on a priority basis. Out of 99 road segments, dealing with first 10 riskiest segments, it covers the problem of $36 \%$ of NOA and $48 \%$ of NOAP, which makes a huge difference. Furthermore, if the first 20 riskiest segments are treated, it will cover $51 \%$ of NOA and $59 \%$ of NOAP. On the other hand, dealing based on equal distribution, this budget has to be distributed to 99 road segments, which cannot be justified, as a series of segments have only one accident and one affected person. Discovering hotspots and positioning and characterizing the potential safety redesign for each spot among a progression of areas are the focal 
goals of studies in motorway safety. In the interim, the improvement of these hazardous fragments to diminish the quantity of accidents requires a great deal of exertion for transportation engineers.

The initial phase during the time spent on highway safety improvement is the identification of hot spots. At that point, deciding the potential improvement for every area and the impact of replacing measures ought to be considered. The number of accidents occurring with reference to traffic exposure has been analyzed in this study. The simplest assessment is to rank the spots based on the ratio method i.e., Number accidents/average annual daily traffic. But to analyze the safety performance of road segments in the presence of multiple variables was difficult. In this paper, a comparative analysis of each spot with a reference riskiest spot has been conducted in order to rank the spots based on severity.

Among developing countries, Pakistan is one of the leading countries with road safety problems, with an eight-times higher accident ratio than that of the US [100]. Road infrastructure and driver culture are the two major factors on the back of increasing road safety problem. The study conducted by [101] shows that drivers' behavior influences the pattern of road traffic accidents. Similarly, higher numbers of accidents occur in hilly areas of Pakistan during glaciation.

In this study, data as based on police and highway authorities, indicating that infrastructural improvement is one of the necessary factors to enhance safety conditions. Police authorities can focus on law enforcement, even on speeding but the problem of infrastructural changes should be focused under policymakers and engineers. Our focus was on drivers' disregard of traffic rules and regulations as well as basic measures including improvements to roads infrastructures, identification of black spots, and monitoring and solving safety problems. It is recommended that a proper mechanism of road safety audit should be there to check the infrastructural suitability for certain traffic pattern and highways.

\subsection{Advantages and Limitations of Using the DEA Method}

DEA technique has several merits over the conventional regression-based production function approach. A few of them are as follows [102-104] quotes as it is in Table 4:

Table 4. Advantages and limitations of using the DEA method.

\begin{tabular}{|c|c|}
\hline Advantages & Limitations \\
\hline $\begin{array}{l}\text { - DEA can deal with multiple inputs and outputs } \\
\text { with a series of units. } \\
\text { - It does not need any assumption of a functional } \\
\text { form relating inputs to outputs. } \\
\text { It sets targets for risk DMUs to make } \\
\text { them efficient. } \\
\text { It estimates a single risk score, identifies input } \\
\text { excesses and output, and provides benchmarks } \\
\text { to monitor the performance of risky } \\
\text { road segments. } \\
\text { It is free from the unit concept. } \\
\text { Relative changes in data in case of homogeneous } \\
\text { DMUs do not effects on the output generated } \\
\text { by DEA. } \\
\text { Selection of inputs and outputs play major role } \\
\text { in calculation of efficiency and risk. } \\
\text { There may be any question about the application } \\
\text { of DEA model but through proper application in } \\
\text { accordance with its weak points it can be applied } \\
\text { widely following the rules and regulations. }\end{array}$ & $\begin{array}{l}\text { - It is a non-parametric technique in which } \\
\text { statistical hypothesis testing is difficult. } \\
\text { It is an extreme point technique because of } \\
\text { which the measurement error cannot } \\
\text { be computed. } \\
\text { Its measured risk is a relative one and therefore, } \\
\text { comparison of the performance of a road } \\
\text { segment can be made with only those segments } \\
\text { which are in the reference set. } \\
\text { It is sensitive to the choice of the input-output } \\
\text { variables and number of road segments. } \\
\text { Its results are also prejudiced by the size of the } \\
\text { sample. If the sample size is small, the } \\
\text { unrestricted power of model reduces. Therefore, } \\
\text { a rule of thumb is that the number of segments } \\
\text { in the dataset should be more than three times of } \\
\text { sum of input and output variables. } \\
\text { It is a computationally intensive method; } \\
\text { however, the availability of DEA software has } \\
\text { made the computation of efficiency scores easy. }\end{array}$ \\
\hline
\end{tabular}




\section{Limitations of the Study}

This research is based on data envelopment analysis method which is a non-parametric technique. This technique has been tested for homogeneous sections of a road i.e., motorways, which is why data variation is relative throughout each section, which does not affect the performance of the model and output. In case of roads with non-homogeneous sections, variables like lane width or number of lanes may be considered to get better output. The DEA method considers the lowest value in case of risk calculation and the highest value in case efficiency as a standard benchmark because it tries to compare the realistic performance approach i.e., minimum one accident occurrence or minimum one killing. Furthermore, this type of study is relevant to the availability of the data quality. In developing countries data quality is an issue which can enhance the accuracy of the analysis.

\section{Conclusions}

This study focuses on the problem of traffic accidents, safety management, and sustainable decision-making. The decision-making procedure involves the safety management for saving human lifves and financial decision-making for safety budget distribution. The data envelopment analysis (DEA) method provides an opportunity to decide about the decision-making units (DMUs) in comparison to best or worst peers among the DMUs. Worldwide, there are four levels of decision-making authorities (i.e., international/countries, federal/national, provincial/states/intercities, and districts/municipal/urban levels) whom deal with the safety managements of roads. In this research, focus was on the federal/national level as motorways are under federal subject in the majority of countries. For safety improvement, technical and financial decision-making processes come in the periphery of transportation engineers. Focusing on the identification of problematic segments of roads, one can easily improve the road safety conditions. Policymakers focus on the methods that can help them to analyze the road safety conditions of highways/motorways, especially during the application of the budget for road safety improvements. Through the prioritization of road segments, budget allocation for road safety improvement can be easily done to improve the road safety conditions. Motorway segments of M-2, within the range of $229 \mathrm{~km}, 223 \mathrm{~km}$, and $246 \mathrm{~km}$ have been found to be the most dangerous, and that is why, priority-wise, a budget will be allocated for these sections for safety improvements. After zooming in, further investigation showed that there was a geometric design problem that was making these segments (i.e., $223 \mathrm{~km}$ and $229 \mathrm{~km}$ ) dangerous for road traffic. The DEA technique is the best possible solution due to easy understanding and implementation to solve the road safety problem. This technique compares the performance of competitive DMUs, which is why no imported formula or equation is required to identify problematic segments. Decision making can be done in the case of any conditions and road infrastructure in any country.

Author Contributions: Conceptualization, S.A.R.S. and N.A.; methodology, S.A.R.S.; software, S.A.R.S.; validation, S.A.R.S.; formal analysis, S.A.R.S.; investigation, S.A.R.S.; resources, S.A.R.S. and N.A.; data curation, S.A.R.S. and N.A.; writing—original draft preparation, S.A.R.S. and N.A.; writing—review and editing, S.A.R.S. and N.A.; supervision, N.A.

Funding: This research received no external funding.

Acknowledgments: We would like to acknowledge Tom Brijs, Ali Pirdavani and Yongjun Shen, for guiding about the application of DEA in road safety.

Conflicts of Interest: The authors declare no conflict of interest.

\section{References}

1. Stoohs, R.A.; Guilleminault, C.; Itoi, A.; Dement, W.C. Traffic accidents in commercial long-haul truck drivers: the influence of sleep-disordered breathing and obesity. Sleep N. Y. 1994, 17, 619-623. [PubMed]

2. Af Wåhlberg, A.; Barraclough, P.; Freeman, J. Personality versus traffic accidents; meta-analysis of real and method effects. Transp. Res. Part F Traffic Psychol. Behav. 2017, 44, 90-104. [CrossRef] 
3. Anand, K. A clinical analysis of outcome in management of head injury in patients with highway road accidents. Int. J. Res. Med. Sci. 2017, 4, 2079-2083.

4. WHO. Global Status Report on Road Safety 2018. WHO: Geneva, Switzerland, 2018.

5. WHO. Global Status Report on Road Safety 2015. WHO: Geneva, Switzerland, 2015.

6. Heydari, S.; Hoseinzadeh, A.; Ghaffarpasand, F.; Hedjazi, A.; Zarenezhad, M.; Moafian, G.; Aghabeigi, M.; Foroutan, A.; Sarikhani, Y.; Peymani, P. Epidemiological characteristics of fatal traffic accidents in Fars province, Iran: A community-based survey. Public Health 2013, 127, 704-709. [CrossRef] [PubMed]

7. Pathak, S.; Jindal, A.; Verma, A.; Mahen, A. An epidemiological study of road traffic accident cases admitted in a tertiary care hospital. Med. J. Armed Forces India 2014, 70, 32-35. [CrossRef] [PubMed]

8. WHO. Pedestrian Safety: A Road Safety Manual for Decision-Makers and Practitioners; World Health Organization: Geneva, Switzerland, 2013.

9. Pan, R.-H.; Chang, N.-T.; Chu, D.; Hsu, K.-F.; Hsu, Y.-N.; Hsu, J.-C.; Tseng, L.-Y.; Yang, N.-P. Epidemiology of orthopedic fractures and other injuries among inpatients admitted due to traffic accidents: A 10-year nationwide survey in Taiwan. Sci. World J. 2014. [CrossRef]

10. DeAngelo, G.; Hansen, B. Life and death in the fast lane: Police enforcement and traffic fatalities. Am. Econ. J. Econ. Policy 2014, 6, 231-257. [CrossRef]

11. Malara, P.; Malara, B.; Drugacz, J. Characteristics of maxillofacial injuries resulting from road traffic accidents-A 5 year review of the case records from Department of Maxillofacial Surgery in Katowice, Poland. Head Face Med. 2006, 2, 27. [CrossRef]

12. Golob, T.F.; Recker, W.W.; Alvarez, V.M. Tool to evaluate safety effects of changes in freeway traffic flow. J. Transp. Eng. 2004, 130, 222-230. [CrossRef]

13. Golob, T.F.; Recker, W.; Pavlis, Y. Probabilistic models of freeway safety performance using traffic flow data as predictors. Saf. Sci. 2008, 46, 1306-1333. [CrossRef]

14. Yasin Çodur, M.; Tortum, A. An Artificial Neural Network Model for Highway Accident Prediction: A Case Study of Erzurum, Turkey. Promet Traffic Transp. 2015, 27, 217-225.

15. Wang, C.; Quddus, M.A.; Ison, S.G. Impact of traffic congestion on road accidents: A spatial analysis of the M25 motorway in England. Accident Anal. Prev. 2009, 41, 798-808. [CrossRef] [PubMed]

16. Ogwueleka, F.N.; Misra, S.; Ogwueleka, T.C.; Fernandez-Sanz, L. An artificial neural network model for road accident prediction: A case study of a developing country. Acta Polytech. Hung. 2014, 11, 177-197.

17. Dadashova, B.; Arenas-Ramírez, B.; Mira-McWilliams, J.; Aparicio-Izquierdo, F. Methodological development for selection of significant predictors explaining fatal road accidents. Accident Anal. Prev. 2016, 90, 82-94. [CrossRef] [PubMed]

18. Pande, A.; Abdel-Aty, M. Assessment of freeway traffic parameters leading to lane-change related collisions. Accident Anal. Prev. 2006, 38, 936-948. [CrossRef] [PubMed]

19. Lord, D.; Manar, A.; Vizioli, A. Modeling crash-flow-density and crash-flow-V/C ratio relationships for rural and urban freeway segments. Accident Anal. Prev. 2005, 37, 185-199. [CrossRef]

20. Imprialou, M.-I.M.; Quddus, M.; Pitfield, D.E.; Lord, D. Re-visiting crash-speed relationships: A new perspective in crash modelling. Accident Anal. Prev. 2016, 86, 173-185. [CrossRef] [PubMed]

21. Givehchi, S.; Hemmativaghef, E.; Hoveidi, H. Association between safety leading indicators and safety climate levels. J. Saf. Res. 2017, 62, 23-32. [CrossRef]

22. Kaye, S.-A.; Lewis, I.; Freeman, J. Comparison of self-report and objective measures of driving behavior and road safety: A systematic review. J. Saf. Res. 2018, 65, 141-151. [CrossRef]

23. Luoma, J.; Sivak, M. Characteristics and availability of fatal road-crash databases in 20 countries worldwide. J. Saf. Res. 2007, 38, 323-327. [CrossRef]

24. Golob, T.F.; Recker, W.W. A method for relating type of crash to traffic flow characteristics on urban freeways. Transp. Res. Part A Policy Pract. 2004, 38, 53-80. [CrossRef]

25. Zhou, M.; Sisiopiku, V. Relationship between volume-to-capacity ratios and accident rates. Transp. Res. Record J. Transp. Res. Board 1997, 1581, 47-52. [CrossRef]

26. Frantzeskakis, J.M.; Iordanis, D.I. Volume-to-capacity ratio and traffic accidents on interurban four-lane highways in Greece. Transp. Res. Record 1987, 1112, 29-38.

27. Abdel-Aty, M.; Lee, J.; Siddiqui, C.; Choi, K. Geographical unit based analysis in the context of transportation safety planning. Transp. Res. Part A Policy Pract. 2013, 49, 62-75. [CrossRef] 
28. Wang, Y.; Kockelman, K.M. A Poisson-lognormal conditional-autoregressive model for multivariate spatial analysis of pedestrian crash counts across neighborhoods. Accident Anal. Prev. 2013, 60, 71-84. [CrossRef] [PubMed]

29. Jovanis, P.P.; Chang, H.-L. Modeling the relationship of accidents to miles traveled. Transp. Res. Record 1986, 1068, 42-51.

30. Martin, J.-L. Relationship between crash rate and hourly traffic flow on interurban motorways. Accident Anal. Prev. 2002, 34, 619-629. [CrossRef]

31. Yeo, H.; Jang, K.; Skabardonis, A.; Kang, S. Impact of traffic states on freeway crash involvement rates. Accident Anal. Prev. 2013, 50, 713-723. [CrossRef] [PubMed]

32. Aljanahi, A.; Rhodes, A.; Metcalfe, A.V. Speed, speed limits and road traffic accidents under free flow conditions. Accident Anal. Prev. 1999, 31, 161-168. [CrossRef]

33. Elvik, R. Effects on accidents of automatic speed enforcement in Norway. Transp. Res. Record J. Transp. Res. Board 1997, 1595, 14-19. [CrossRef]

34. Elvik, R.; Christensen, P.; Amundsen, A. Speed and Road Accidents. An Evaluation of the Power Model; TØI report: Oslo, Norway, 2004.

35. Garber, N.; Ehrhart, A. Effect of speed, flow, and geometric characteristics on crash frequency for two-lane highways. Transp. Res. Record J. Transp. Res. Board 2000, 1717, 76-83. [CrossRef]

36. Kononov, J.; Lyon, C.; Allery, B. Relation of flow, speed, and density of urban freeways to functional form of a safety performance function. Transp. Res. Record J. Transp. Res. Board 2011, 11-19. [CrossRef]

37. Malyshkina, N.; Mannering, F. Effect of increases in speed limits on severities of injuries in accidents. Transp. Res. Record J. Transp. Res. Board 2008, 2083, 122-127. [CrossRef]

38. Hamzeie, R.; Savolainen, P.T.; Gates, T.J. Driver speed selection and crash risk: Insights from the naturalistic driving study. J. Saf. Res. 2017, 63, 187-194. [CrossRef] [PubMed]

39. Golob, T.F.; Recker, W.W. Relationships among urban freeway accidents, traffic flow, weather, and lighting conditions. J. Transp. Eng. 2003, 129, 342-353. [CrossRef]

40. Karlaftis, M.G.; Golias, I. Effects of road geometry and traffic volumes on rural roadway accident rates. Accident Anal. Prev. 2002, 34, 357-365. [CrossRef]

41. Milton, J.C.; Mannering, F.L. The Relationship Between Highway Geometrics, Traffic Related Elements, and Motor Vehicle Accidents; Springer: Berlin/Heidelberg, Germany, 1996.

42. Noland, R.B.; Oh, L. The effect of infrastructure and demographic change on traffic-related fatalities and crashes: A case study of Illinois county-level data. Accident Anal. Prev. 2004, 36, 525-532. [CrossRef]

43. Fu, R.; Guo, Y.; Yuan, W.; Feng, H.; Ma, Y. The correlation between gradients of descending roads and accident rates. Saf. Sci. 2011, 49, 416-423. [CrossRef]

44. Wang, B.; Hallmark, S.; Savolainen, P.; Dong, J. Crashes and near-crashes on horizontal curves along rural two-lane highways: Analysis of naturalistic driving data. J. Saf. Res. 2017, 63, 163-169. [CrossRef]

45. Benz, T.; Gaitanidou, E.; Tapani, A.; Toffolo, S.; Yannis, G.; Spyropoulou, I. Models on the Road. In Infrastructure and Safety in a Collaborative World; Springer: Berlin/Heidelberg, Germany, 2011; pp. 97-124.

46. Bergel-Hayat, R.; Debbarh, M.; Antoniou, C.; Yannis, G. Explaining the road accident risk: Weather effects. Accident Anal. Prev. 2013, 60, 456-465. [CrossRef]

47. Commandeur, J.J.; Bijleveld, F.D.; Bergel-Hayat, R.; Antoniou, C.; Yannis, G.; Papadimitriou, E. On statistical inference in time series analysis of the evolution of road safety. Accident Anal. Prev. 2013, 60, 424-434. [CrossRef] [PubMed]

48. Yannis, G.; Laiou, A.; Folla, K.; Bauer, R.; Machata, K.; Brandstaetter, C. Comparative analysis of road safety parameters in the European motorways. In Proceedings of the 1st European Road Infrastructure Congress, Leeds, UK, 18-20 October 2016.

49. Yannis, G.; Papadimitriou, E.; Chaziris, A.; Duchamp, G.; Lejeune, P.; Treny, V.; Hemdorff, S.; Haddak, M.; Lenguerrand, E.; Hollo, P. Building the European Road Safety Observatory. SafetyNet. Deliverable 2.3 Risk Exposure Data Common Framework; European Commission, Directorate-General Transport and Energy, Loughborough University: Leicestershire, UK, 2008.

50. Yannis, G.; Papadimitriou, E.; Dupont, E.; Martensen, H. Estimation of fatality and injury risk by means of in-depth fatal accident investigation data. Traffic Inj. Prev. 2010, 11, 492-502. [CrossRef] [PubMed] 
51. Yannis, G.; Dragomanovitsa, A.; Laioua, A.; La Torreb, F.; Domenichinib, L.; Richterc, T.; Ruhlc, S.; Grahamd, D.; Karathodoroud, N. Development of an online Repository of Accident Prediction Models and Crash Modification Factors. In Proceedings of the 1st European Road Infrastructure Congress, Leeds, UK, 18-20 October 2016.

52. Yannis, G.; Papadimitriou, E.; Evgenikos, P. Cost-benefit assessment of selected road safety measures in Greece. In Proceedings of the 13th International Conference on Road Safety on Four Continents, Warsaw, Poland, 5-7 October 2005.

53. Yannis, G.; Evgenikos, P.; Papadimitriou, E. Best practice for cost-effective road safety infrastructure investments. In Proceedings of the Conference of European Directors of Road (CEDR), Paris, France, 2 April 2008.

54. Papadimitriou, E.; Filtness, A.; Theofilatos, A.; Ziakopoulos, A.; Quigley, C.; Yannis, G. Review and ranking of crash risk factors related to the road infrastructure. Accident Anal. Prev. 2019, 125, 85-97. [CrossRef] [PubMed]

55. Yannis, G.; Dragomanovits, A.; Laiou, A.; Richter, T.; Ruhl, S.; La Torre, F.; Domenichini, L.; Graham, D.; Karathodorou, N.; Li, H. Use of accident prediction models in road safety management-an international inquiry. Transp. Res. Procedia 2016, 14, 4257-4266. [CrossRef]

56. Yannis, G.; Papadimitriou, E.; Evgenikos, P.; Dragomanovits, A. Good practices on cost-effective road infrastructure safety investments. Int. J. Inj. Control Saf. Promot. 2016, 23, 373-387. [CrossRef] [PubMed]

57. Bishai, D.; Hyder, A.A.; Ghaffar, A.; Morrow, R.H.; Kobusingye, O. Rates of public investment for road safety in developing countries: case studies of Uganda and Pakistan. Health Policy Plan. 2003, 18, $232-235$. [CrossRef] [PubMed]

58. WHO. Global Status Report on Road Safety: Time for Action; World Health Organization: Geneva, Switzerland, 2009.

59. Hyder, A.A.; Ghaffar, A.; Masood, T.I. Motor vehicle crashes in Pakistan: The emerging epidemic. Inj. Prev. 2000, 6, 199-202. [CrossRef]

60. PBS. Accident Data Statistics. Available online: http://www.pbs.gov.pk/sites/default/files//tables/Data\% 20on\%20Traffic\%20Accidents.pdf (accessed on 20 August 2018).

61. Yu, H.; Liu, P.; Chen, J.; Wang, H. Comparative analysis of the spatial analysis methods for hotspot identification. Accident Anal. Prev. 2014, 66, 80-88. [CrossRef]

62. Qu, X.; Meng, Q. A note on hotspot identification for urban expressways. Saf. Sci. 2014, 66, 87-91. [CrossRef]

63. Borsos, A.; Cafiso, S.; D'Agostino, C.; Miletics, D. Comparison of Italian and Hungarian Black Spot Ranking. Transp. Res. Procedia 2016, 14, 2148-2157. [CrossRef]

64. Sorate, R.; Kulkarni, R.; Bobade, S.; Patil, M.; Talathi, A.; Sayyad, I.; Apte, S. Identification of accident black spots on national highway 4 (New Katraj tunnel to Chandani chowk). IOSR J. Mech. Civ. Eng. E ISSN 2015, 12, 61-67.

65. Sohadi, R.U.R.; Baguley, C. The Identification, Prioritising and Analysis of Accident Blackspots In Malaysia; TRL Transport Research Laboratory: Wokingham, UK, 1994.

66. Washington, S.; Haque, M.; Oh, J.; Lee, D. Identifying Black Spots Using Property Damage Only Equivalency (PDOE) Factors. In Proceedings of the 16th International Conference Road Safety on Four Continents, Beijing, China, 15-17 May 2013. (RS4C 2013).

67. BHS. Sequential Data Analysis for Black Spot Identification. In Proceedings of the 4th IRTAD Conference, Oral Presentations, Seoul, Korea, 16-17 September 2009; pp. 219-222.

68. Elvik, R. State-of-the-Art Approaches to Road Accident Black Spot Management and Safety Analysis of Road Networks; Transportøkonomisk institutt: Oslo, Norway, 2007.

69. Elvik, R. Comparative analysis of techniques for identifying locations of hazardous roads. Transp. Res. Record 2008, 01, 72-75. [CrossRef]

70. Mustakim, F.; Busu, A. Identifying, prioritizing and treating hazardous location at Federal Route FT023 (Muar-Segamat). In Malaysian Road Conference, 7th; Ministry of Work Malaysia: Kuala Lumpur, Malaysia, 2007.

71. Hauer, E.; Persaud, B.N. Problem of identifying hazardous locations using accident data. Transp. Res. Record 1984, 975, 36-43. 
72. Vistisen, D.; Thyregod, P.; Laursen, J.G. Models and Methods for Hot Spot Safety Work; Technical University of DenmarkDanmarks Tekniske Universitet, Department of PlanningInstitut for Planlægning: Lyngby, Denmark, 2002.

73. Ghadi, M.; Török, Á. A comparative analysis of black spot identification methods and road accident segmentation methods. Accident Anal. Prev. 2019, 128, 1-7. [CrossRef] [PubMed]

74. Debrabant, B.; Halekoh, U.; Bonat, W.H.; Hansen, D.L.; Hjelmborg, J.; Lauritsen, J. Identifying traffic accident black spots with Poisson-Tweedie models. Accident Anal. Prev. 2018, 111, 147-154. [CrossRef] [PubMed]

75. Wegman, F. Road Accidents: Worldwide A Problem that Can Be Tackled Successfully; Permanent International Association of Road Congresses, Ed.; SWOV: Paris, France, 1996.

76. Wegman, F.; Lynam, D.; Nilsson, G. SUNflower: A Comparative Study of the Developments of Road Safety in Sweden, the United Kingdom, and the Netherlands; SWOV Institute for Road Safety Research: Leidschendam, The Netherlands, 2002.

77. Wegman, F.C.; Aarts, L. Advancing Sustainable Safety: National Road Safety Outlook for 2005-2020; SWOV Institute for Road Safety Research: Leidschendam, The Netherlands, 2006.

78. Hagenzieker, M.P.; Commandeur, J.J.; Bijleveld, F.D. The history of road safety research: A quantitative approach. Transp. Res. Part F Traffic Psychol. Behav. 2014, 25, 150-162. [CrossRef]

79. AF Wåhlberg, A. Driver Behaviour and Accident Research Methodology: Unresolved Problems; Ashgate Publishing, Ltd.: Farnham, France, 2012.

80. Wegman, F.; Berg, H.-Y.; Cameron, I.; Thompson, C.; Siegrist, S.; Weijermars, W. Evidence-based and data-driven road safety management. IATSS Res. 2015, 39, 19-25. [CrossRef]

81. Shinar, D.; Gurion, B. Crash causes, countermeasures, and safety policy implications. Accident Anal. Prev. 2019, 125, 224-231. [CrossRef]

82. Michalaki, P.; Quddus, M.A.; Pitfield, D.; Huetson, A. Exploring the factors affecting motorway accident severity in England using the generalised ordered logistic regression model. J. Saf. Res. 2015, 55, 89-97. [CrossRef]

83. Turner, D.; Thomas, R. Motorway accidents: An examination of accident totals, rates and severity and their relationship with traffic flow. Traffic Eng. Control 1986, 27, 377-383.

84. Montella, A.; Colantuoni, L.; Lamberti, R. Crash prediction models for rural motorways. Transp. Res. Record 2008, 2083, 180-189. [CrossRef]

85. Montella, A. A comparative analysis of hotspot identification methods. Accident Anal. Prev. 2010, 42, 571-581. [CrossRef] [PubMed]

86. Montella, A.; Persaud, B.; D'Apuzzo, M.; Imbriani, L.L. Safety evaluation of automated section speed enforcement system. Transp. Res. Record 2012, 2281, 16-25. [CrossRef]

87. Abdel-Aty, M.A.; Radwan, A.E. Modeling traffic accident occurrence and involvement. Accident Anal. Prev. 2000, 32, 633-642. [CrossRef]

88. Garber, N.J.; Subramanyan, S. Feasibility of Incorporating Crash Risk in Developing Congestion Mitigation Measures for Interstate Highways: A Case Study of the Hampton Roads Area; Virginia Transportation Research Council: Charlottesville, VA, USA, 2002.

89. Abdel-Aty, M.; Pande, A. Identifying crash propensity using specific traffic speed conditions. J. Saf. Res. 2005, 36, 97-108. [CrossRef] [PubMed]

90. Baruya, A. Speed-Accident Relationships on Different Kinds of European Roads; Transport Research Laboratory: Wokingham, UK, 1998.

91. Balkin, S.; Ord, J.K. Assessing the impact of speed-limit increases on fatal interstate crashes. J. Transp. Stat. 2001, 4, 1-26.

92. Montella, A.; Imbriani, L.L.; Marzano, V.; Mauriello, F. Effects on speed and safety of point-to-point speed enforcement systems: Evaluation on the urban motorway A56 Tangenziale di Napoli. Accident Anal. Prev. 2015, 75, 164-178. [CrossRef]

93. NH\&MP. Accident Data; National Highway \& Motorway Police (Data Centre): Islamabad, Pakistan, 2015.

94. Shah, S.A.R.; Brijs, T.; Ahmad, N.; Pirdavani, A.; Shen, Y.; Basheer, M.A. Road Safety Risk Evaluation Using GIS-Based Data Envelopment Analysis-Artificial Neural Networks Approach. Appl. Sci. 2017, 7, 886. [CrossRef] 
95. Shah, S.A.R.; Ahmad, N.; Shen, Y.; Pirdavani, A.; Basheer, M.A.; Brijs, T. Road Safety Risk Assessment: An Analysis of Transport Policy and Management for Low-, Middle-, and High-Income Asian Countries. Sustainability 2018, 10, 389. [CrossRef]

96. Delorme, R.; Lassarre, S. A new theory of complexity for safety research. The case of the long-lasting gap in road safety outcomes between France and Great Britain. Saf. Sci. 2014, 70, 488-503. [CrossRef]

97. Papadimitriou, E.; Yannis, G.; Bijleveld, F.; Cardoso, J.L. Exposure data and risk indicators for safety performance assessment in Europe. Accident Anal. Prev. 2013, 60, 371-383. [CrossRef] [PubMed]

98. Shah, S.A.R.; Ahmad, N.; Shen, Y.; Kamal, M.A.; Basheer, M.A.; Brijs, T. Relationship between road traffic features and accidents: An application of two-stage decision making approach for transportation engineers. J. Saf. Res. 2019, 69, 201-215. [CrossRef]

99. Bishai, D.; Quresh, A.; James, P.; Ghaffar, A. National road casualties and economic development. Health Econ. 2006, 15, 65-81. [CrossRef] [PubMed]

100. Batool, Z.; Carsten, O.; Jopson, A. Road safety issues in Pakistan: A case study of Lahore. Transp. Plan. Technol. 2012, 35, 31-48. [CrossRef]

101. Toor, Y.; Muhlethaler, P.; Laouiti, A. Vehicle ad hoc networks: Applications and related technical issues. IEEE Commun. Surv. Tutor. 2008, 10. [CrossRef]

102. Amirteimoori, A.; Kordrostami, S. Allocating fixed costs and target setting: A DEA-based approach. Appl. Math. Comput. 2005, 171, 136-151. [CrossRef]

103. Hermans, E.; Brijs, T.; Wets, G.; Vanhoof, K. Benchmarking road safety: Lessons to learn from a data envelopment analysis. Accident Anal. Prev. 2009, 41, 174-182. [CrossRef] [PubMed]

104. Yang, J.-B.; Wong, B.Y.; Xu, D.-L.; Stewart, T.J. Integrating DEA-oriented performance assessment and target setting using interactive MOLP methods. Eur. J. Oper. Res. 2009, 195, 205-222. [CrossRef]

(C) 2019 by the authors. Licensee MDPI, Basel, Switzerland. This article is an open access article distributed under the terms and conditions of the Creative Commons Attribution (CC BY) license (http://creativecommons.org/licenses/by/4.0/). 